\title{
Characterization of Pinus ectomycorrhizas from mixed conifer and pygmy forests using morphotyping and molecular methods
}

\author{
Nina Wurzburger, Martin I. Bidartondo, and Caroline S. Bledsoe
}

\begin{abstract}
We used morphotyping and molecular methods to characterize ectomycorrhizas of bishop pine (Pinus muricata D. Don) and Bolander pine (Pinus contorta ssp. bolanderi (Parl.) Critchf.) from mixed conifer and hydric pygmy forests on the northern California coast. Sixteen ectomycorrhizal morphotypes were described, producing 15 internal transcribed spacer restriction fragment length polymorphism (ITS-RFLP) types, and 12 were identified via ITS sequencing. From a given site, all root tips of a specific morphotype produced identical ITS-RFLP patterns. However, sometimes two morphotypes produced the same ITS-RFLP type, and sometimes samples of the same morphotype from two different sites produced two different ITS-RFLP types. These results indicate that surveys of ectomycorrhizal fungi based on morphology alone are not sufficient, and that grouping morphotypes prior to molecular analysis can expedite the process. Ectomycorrhizas from mixed conifer included Russuloid sp., Tomentella sublilacina (Ellis \& Holw.) Wakef., Tuber sp., and two Thelephoroid species. Ectomycorrhizas from hydric pygmy included two Dermocybe spp., a Cortinarius sp., two Thelephoroid spp., and Suillus tomentosus (Kauffman) Singer. Both plant communities contained Cenococcum geophilum Fr.:Fr. The hydric pygmy sites were more similar to each other than to the mixed conifer site (Jaccard similarity). The presence of ectomycorrhizal taxa in one plant community type may reflect biotic (host specificity) or abiotic (soil fertility or hydrology) adaptation.
\end{abstract}

Key words: ectomycorrhiza, bishop pine, Pinus muricata, Bolander pine, Pinus contorta ssp. bolanderi, morphotyping, ITS-RFLP.

\begin{abstract}
Résumé : Les auteurs ont utilisé des méthodes de caractérisation morphologique et moléculaire pour classifier les ectomycorhizes du pin Bishop (Pinus muricata D. Don) et du pin Bolander (Pinus contorta ssp. bolanderi (Parl. Crithf.) venant dans des forêts conifériennes mixtes et naines hydriques de la côte du nord de la Californie. Les auteurs décrivent 16 morphotypes d'ectomycorhize et présentent 15 types d' ITS-RFLP, dont 12 identifiés via le séquençage des ITS. Pour un site donné, tous les apex racinaires d'un morphotype spécifique produisent des patrons ITS-RFLP identiques. Quelques fois cependant, 2 morphotypes produisent le même type d'ITS-RFLP, et à l'occasion des échantillons du même morphotype provenant de deux sites différents produisent deux types de ITS-RFLP distincts. Ces résultats indiquent que l'observation des ectomycorhizes basée sur la seule morphologie n'est pas suffisante et que le regroupement de morphotypes avant l'analyse moléculaire, constitue un procédé expéditif. Les ectomycorhizes de la forêt coniférienne mixte incluent une espèce russullö̈de, le Tomentella sublilacina (Ellis \& Holw.) Wakef., un Tuber sp., et deux espèces théléphorioïdes. Les ectomycorhizes de la forêt naine humide incluent deux Dermacybe spp., un Cortinarius sp., deux espèces théléphorioïdes, et le Suillus tomentosus (Kauffman) Singer. Les deux communautés végétales contiennent du Cenococcum geophilum Fr.:Fr. Les sites de forêt naine hydrique se ressemblent plus l'un l'autre que le site de forêt coniférienne mixte (similarité de Jaccard). La présence des taxons ectomycorhiziens dans un type de communauté végétale peut refléter une adaptation biotique (spécificité à l'hôte) ou abiotique (fertilité du sol ou hydrologie).
\end{abstract}

Mots clés : ectomycorhize, pin Bishop, Pinus muricta, pin Bolander, Pinus contorta ssp. bolanderi, morphotypage ITS-RFLP.

[Traduit par la Rédaction]

Received December 8, 2000. Published on the NRC Research Press Web site at http://canjbot.nrc.ca on October 5, 2001.

N. Wurzburger ${ }^{1,2}$ and C.S. Bledsoe. Department of Land, Air, and Water Resources, 1 Shields Avenue, University of California, Davis, CA 95616-8627, U.S.A.

M.I. Bidartondo. Department of Plant and Microbial Biology, University of California, Berkeley, CA 94720-3102, U.S.A.

${ }^{1}$ Corresponding author (e-mail: wurzburg@arches.uga.edu).

${ }^{2}$ Present address: Warnell School of Forest Resources, University of Georgia, Athens, GA 30602-2152 U.S.A. 


\section{Introduction}

Ectomycorrhizal (ECM) fungi are functionally important in temperate forest ecosystems for plant nutrient and water uptake and provide protection from root pathogens (Smith and Read 1997). ECM fungi are diverse (5000-6000 species; Molina et al. 1992), and studies of ECM community structure have revealed remarkable belowground richness (tens to hundreds of species) in relatively small areas (Stendell et al. 1999). This richness in ECM species is coupled with diverse physiological characteristics across taxa, from nutrient acquisition to $\mathrm{pH}$ tolerance (Allen et al. 1995; Cairney 1999). Despite numerous studies of ECM physiology in culture, the response of the ECM community to different edaphic conditions in natural systems is poorly understood. In the few available examples, ECM communities differ across soil types (Gehring et al. 1998), forest types (Goodman and Trofymow 1998), and fire regimes (Visser 1995).

A series of marine terraces on the northern California coast provides a strong gradient of soil weathering and fertility. Both mixed conifer and hydric pygmy plant community types are located along these uplifted marine terraces near Fort Bragg and Mendocino, Calif. Coastal mixed conifer forests have well-drained, more fertile soils, while older terraces further inland are occupied by hydric pygmy forests that developed on poorly drained, less fertile soils. Sites, plant species distribution, and soil analyses have been described elsewhere (Wurzburger and Bledsoe 2001). In a previous study, we observed differences in the ECM morphotype community in mixed conifer and pygmy plant community types; some ECM types were found across community types, while others were specific to one type (Wurzburger and Bledsoe 2001). The distribution of ECM morphotypes in these plant communities could reflect their adaptation. It is, therefore, valuable to determine the taxonomic integrity of these ECM morphotypes.

ECM communities have been evaluated by the presence of sporocarps; however, this method poorly represents the ECM taxa present on root tips (Egger 1995; Gardes and Bruns 1996a). ECM morphotyping directly from ECM root tips (Agerer 1991) is more effective, because it can evaluate ECM fungal diversity based on vegetative structures instead of sexual structures and allows the determination of host specificity patterns (Goodman and Trofymow 1998; Kranabetter et al. 1999; Massicotte et al. 1999). Morphotyping can be performed relatively rapidly; however, it is a limiting technique, because the morphology of a particular fungal taxon can change with different hosts and environments (Egger 1995). A more precise determination of diversity and identification of ECM fungal species can be obtained using polymerase chain reaction (PCR) and restriction fragment length polymorphisms (RFLP) of the internal transcribed spacer (ITS) of the fungal nuclear ribosomal repeat (Egger 1995; Gardes and Bruns 1993).

The objective of this study was to characterize ECM from two different plant communities using two methods: ECM morphotyping and molecular identification. We characterized bishop pine (Pinus muricata D. Don) and Bolander pine (Pinus contorta ssp. bolanderi (Parl.) Critchf.) ECM from a mixed conifer and a hydric pygmy plant community, respectively. We hypothesized that (i) ECM taxa would differ between the mixed conifer and hydric pygmy plant communities, and (ii) typing ECM mycorrhizas by morphotyping would provide a conservative estimation of ECM richness compared with ITS-RFLP typing. We tested these hypotheses by (i) morphotyping roots from the mixed conifer and hydric pygmy plant communities, (ii) identifying ECM fungal taxa (ITS-RFLP and sequencing of the ITS), and (iii) comparing results obtained from ECM morphotyping and molecular methods.

\section{Materials and methods}

\section{ECM root and sporocarp collection}

In June 1999, Pinus spp. roots were collected from a mixed conifer site and two hydric pygmy sites: hydric pygmy 1 and 2. Sites were located in the Jug Handle State Reserve and the Jackson State Forest, between Fort Bragg and Mendocino on the northern California coast (see Wurzburger and Bledsoe (2001) for site descriptions). Root fragments and associated ECM lateral roots were collected from small pits in the $\mathrm{O}$ horizon, each sample representing about $1000 \mathrm{~cm}$ of fine (ECM) root length. At the mixed conifer site, samples were collected from two groves of $P$. muricata (three samples per grove, six samples total). At each hydric pygmy site, samples were collected under four trees of $P$. contorta ssp. bolanderi (one sample per tree, four samples per site). ECM roots of Pinus spp. have characteristic branching patterns (dichotomous and coralloid) and could be differentiated from roots of other plant species. Hypogeous sporocarps and sclerotia associated with ECM roots were also collected at the time of root sampling. Roots, collected with soil to minimize disturbance to mycorrhizal characteristics, were placed in a cooler, transported to the laboratory, and stored at $4^{\circ} \mathrm{C}$.

\section{ECM evaluation}

Roots were washed gently and all ECM root tips were characterized within 10 days of sampling on the basis of color, texture, presence of emanating hyphae or rhizomorphs, mantle patterns, and Hartig net (Agerer 1991). Rare ECM morphotypes were evaluated only by color and texture. Several tips of each morphotype (5-15), sporocarp tissue, and sclerotia were frozen at $-20^{\circ} \mathrm{C}$ until lyophilized for a total of 170 root tips and 10 sporocarp or sclerotia samples.

\section{Molecular analyses}

DNA was extracted from individual ECM root tips, hypogeous sporocarps, and sclerotia (Gardes and Bruns 1996b). The ITS region, located between the $18 \mathrm{~S}$ and $28 \mathrm{~S}$ rRNA genes, was amplified using the primer pair ITS1-F and ITS4 by PCR (White et al. 1990; Gardes and Bruns 1993). Eighty-four percent of the samples amplified. We characterized the amplified ITS region by restriction enzyme digestion (HinfI and AluI; New England Biolabs Inc., Beverly, Mass.), followed by electrophoresis. Fragment lengths were quantified and compared (GelReader version 2.0.5; National Center for Supercomputing Applications, Champaign, Ill.).

Prior to sequencing, each ITS-RFLP type was reamplified with the same primers, and purified with a Qiagen QIAquick PCR purification kit (Qiagen Inc., Valencia, Calif.). Cycle-sequencing reactions were performed with each primer using the ABI Big Dye terminator kit (PE Applied Biosystems, Foster City, Calif.) and analyzed on an ABI model 377 DNA sequencer (Perkin-Elmer Corporation). Two-directional sequences from each sample were analyzed with Sequence Navigator software. Sequences were subjected to a GenBank search and those with $99 \%$ similarity to those in GenBank were considered a match for species identification. Sequences with less similarity $(<99 \%)$ were identified to genus or family groups. 
Table 1. Descriptions of Pinus spp. ectomycorrhizal morphotypes found in mixed conifer (MC) and two hydric pygmy (HP1, HP2) plant communities.

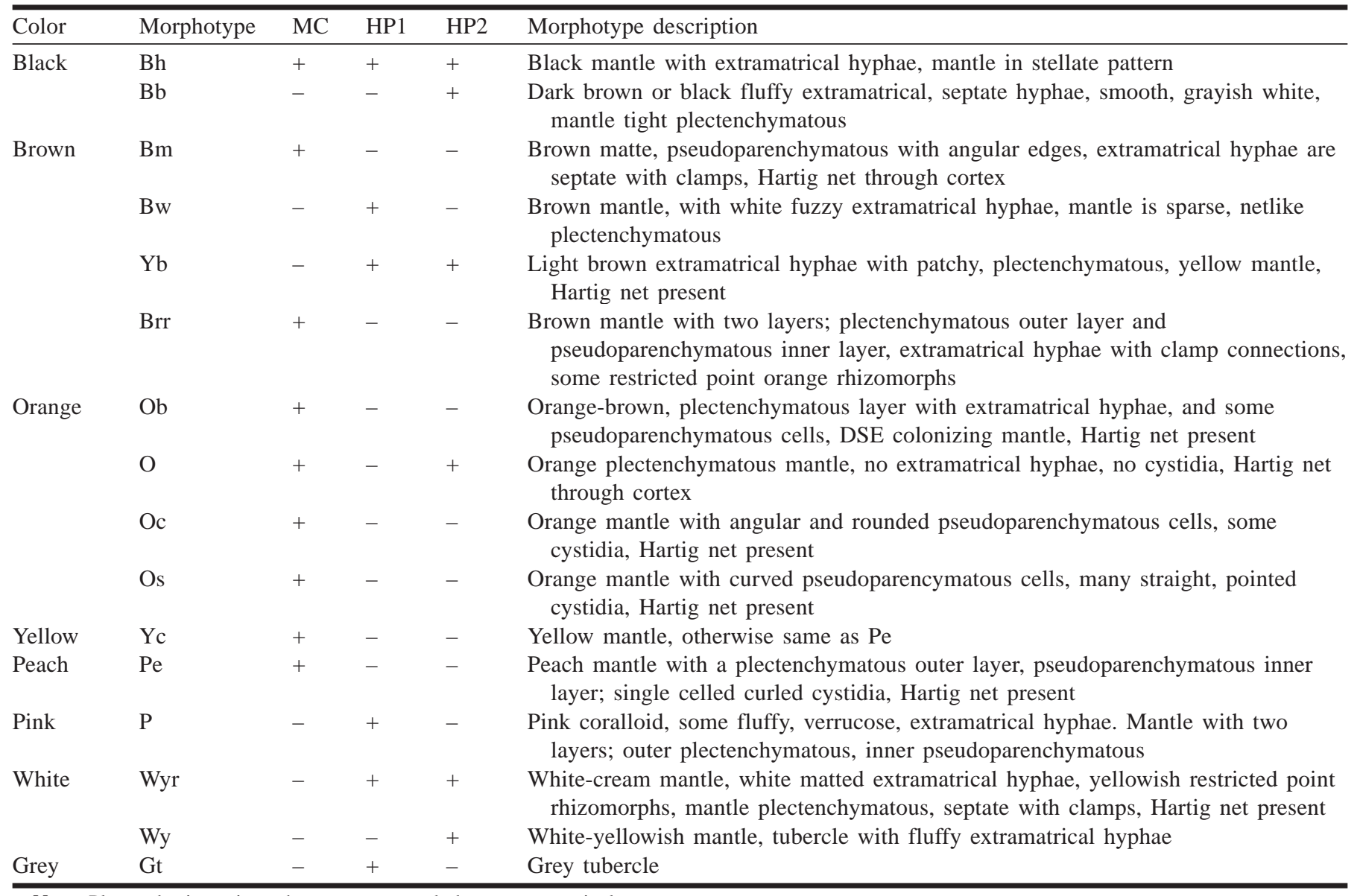

Note: Plus and minus signs show presence and absence, respectively.

\section{Results}

\section{ECM morphotypes}

Sixteen ECM morphotypes were characterized, nine each from the mixed conifer and hydric pygmy communities (Table 1). One ECM morphotype (Bh) was found on every site, and two morphotypes were found on both hydric pygmy 1 and 2 (Wyr and $\mathrm{Yb})$.

\section{ITS-RFLP analyses}

From each site, all samples within each ECM morphotype produced identical RFLP patterns (data not presented). Fifteen distinct ITS-RFLP types were determined (Table 2). Cenococcum geophilum sclerotia and Tuber species sporocarps were collected from the mixed conifer community type and compared with the RFLP patterns of root tips. The RFLP patterns from the Tuber sp. sporocarp and morphotype Os matched, as did C. geophilum sclerotia and morphotype Bh.

In the mixed conifer community, nine ECM morphotypes produced only six ITS-RFLP types because three pairs of morphotypes, $\mathrm{Oc}$ and $\mathrm{O}, \mathrm{Ob}$ and $\mathrm{Brr}$, and $\mathrm{Pe}$ and $\mathrm{Yc}$, produced identical ITS-RFLP patterns. In the hydric pygmy community type, nine morphotypes produced 10 ITS-RFLP types. Morphotype Gt did not amplify and, therefore, was not typed. In both hydric pygmy 1 and 2, each tip of morphotype Bh consisted of two ITS types ( 2 and $2 b$ ).
Morphotype Wyr produced the same RFLP pattern on both sites, while $\mathrm{Yb}$ and $\mathrm{O}$ did not. On hydric pygmy 2, morphotype $\mathrm{Yb}$ produced the same ITS type (7) as did morphotype Wyr. However, on hydric pygmy 1, morphotype $\mathrm{Yb}$ produced ITS-RFLP type 6. ITS-RFLP types 1 and 2 (C. geophilum) and $2 \mathrm{~b}$ (Phialophora-like) were identified by their RFLP patterns from previous studies (Table 2).

\section{ITS sequence identification}

Eleven taxa were identified via ITS sequencing. Three ITS-RFLP types $(1,2$, and 2b) were identified based on comparisons of RFLP patterns from previous studies, and two types (ITS-RFLP type 9 and morphotype Gt) remain unidentified. Three taxa were identified to species groups (Cenococcum geophilum, Tomentella sublilacina, and Suillus tomentosus), four identified to genus (Tuber sp., Dermocybe sp.1, Dermocybe sp.2, Cortinarius sp.), and five were identified to a family level (Thelephoroid 1-4, Russuloid 1).

Eleven sequences were compared with those in GenBank via basic local alignment search tool (BLAST) searches. Two ITS-RFLP types were identified to species: Tomentella sublilacina (99\% similar to U83481.1 over 682 base pairs (bp)) and Suillus tomentosus (99\% similar to U74614 over $478 \mathrm{bp}$ ). Other ITS-RFLP types were identified to genus, $T u$ ber sp. (92\% similar to Tuber puberulum AF003918 over 605 bp), Dermocybe sp. 2 (87\% similar to Dermocybe sp. U56073 
Table 2. A comparison of morphotypes and ITS-RFLP types.

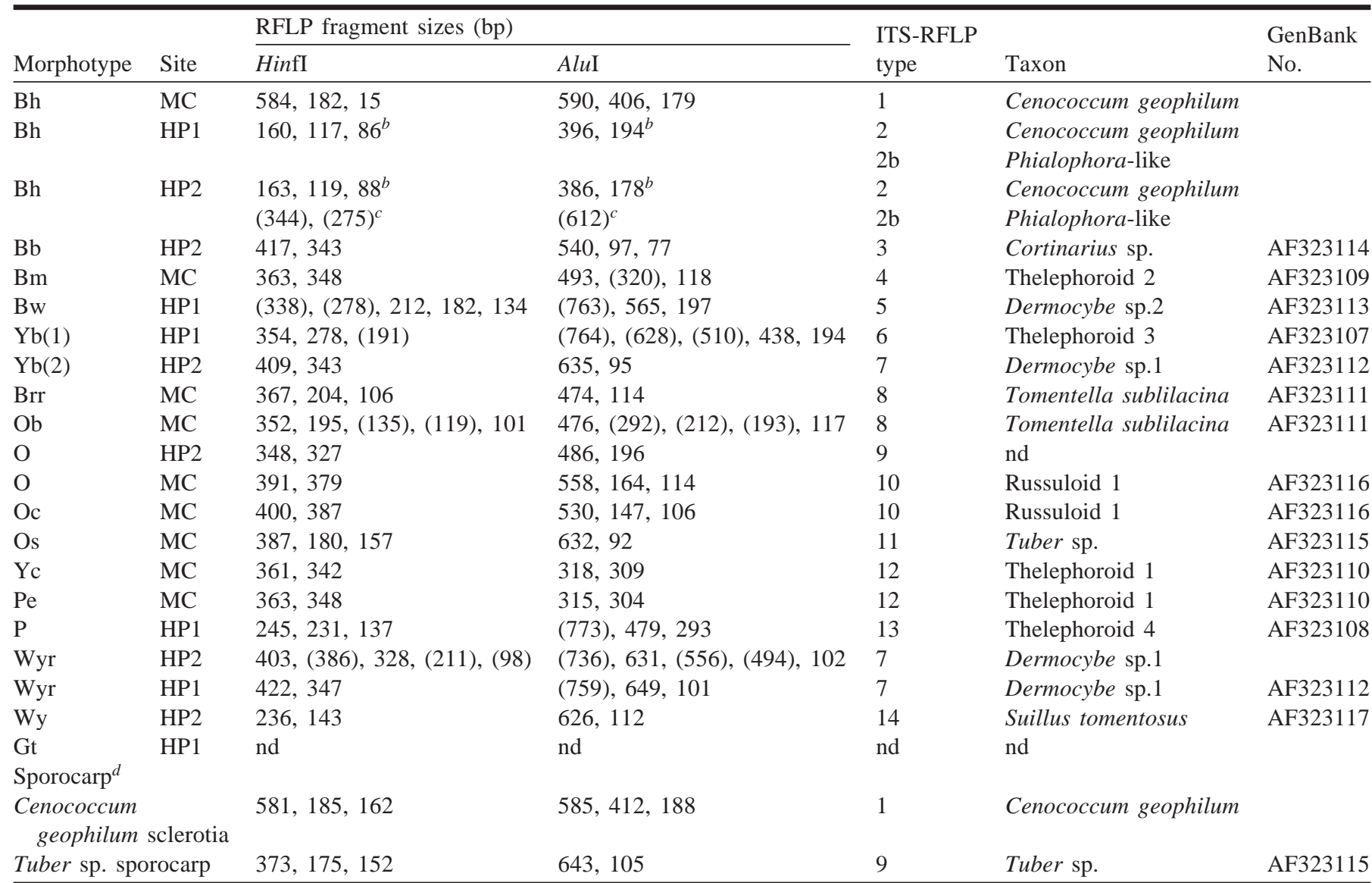

\footnotetext{
Note: Restriction digest band lengths ( $b p$, HinfI and AluI), taxon, and GenBank numbers derived from 16 ECM morphotypes. Site abbreviations are as follows: MC, mixed conifer; HP1, hydric pygmy 1; HP2, hydric pygmy 2. Band sizes are in base pair units, bands in parentheses are submolar. nd, not determined.

${ }^{b}$ RFLP pattern similar to Cenococcum geophilum I (HinfI, 160, 119, 92, AluI, 387, 194; Horton and Bruns 1998). ${ }^{c}$ RFLP pattern similar to Phialophora-like (HinfI 345, 273, AluI 600; Baar et al. 1999).

${ }^{d}$ Sporocarp samples collected from the mixed conifer site.
}

ITS over 644 bp), and Cortinarius sp. (97\% similar to Cortinarius mucosus AF182801 ITS over 334 bp). The sequence for Dermocybe sp. 1 (96\% similar to Dermocybe semisanguinea U56066 ITS over 668 bp) was derived from morphotype Wyr from hydric pygmy 1 (morphotype Wyr from hydric pygmy 2 was identified based on ITS-RFLP similarity to Wyr from hydric pygmy 1, and morphotype $\mathrm{Yb}(2)$ from hydric pygmy 2 produced an identical sequence).

The remaining five ITS-RFLP types were identified by family group, Russuloid $(92 \%$ similar to Lactarius subsericatus AF140261 over 700 bp), Thelephoroid 1 (92\% similar to Thelephora penicillata U83484.1 over 659 bp), Thelephoroid 2 (94\% similar to Thelephoraceae sp. Taylor No. 7 U83476.1 over 651 bp), Thelephoroid 3 (88\% similar to Thelephoraceae sp. Taylor No. 7 U83476.1 over 247 bp), and Thelephoroid 4 (88\% similar to Thelephoraceae sp. AF184742 over 225 bp). Although Thelephoroid 2 and 3 are both similar to Thelephoraceae sp. Taylor No. 7 U83476.1, they differ based on ITS-RFLP patterns (Table 2).

\section{Comparison of ECM from 1998 and 1999}

Our ECM morphotyping data (1999) were compared with data collected in 1998 (Wurzburger and Bledsoe 2001). ECM types changed from 1998 to 1999. Seven types (Tuber sp., Tomentella sublilacina, C. geophilum, Thelephoroid 2, Russuloid 1, Thelephoroid 4, and ITS-RFLP type 9) were observed in both 1998 and 1999. Twelve types were observed in only 1 of the 2 years: morphotypes Y, Brg, Wr, G, and Brm in 1998; Thelephoroid 1, Thelephoroid 3, Dermocybe sp.2, morphotype Gt, Cortinarius sp., Dermocybe sp.1, and Suillus tomentosus in 1999.

During 1998 and 1999, two types (C. geophilum and morphotype Y) were observed on all three sites, and three types were observed on both hydric pygmy sites (Dermocybe sp.1, ITS-RFLP type 9, and Thelephoroid 4). Each site was also composed of several (three to seven) unique types. However, a Jaccard similarity analysis revealed that hydric pygmy 1 and 2 were more similar to each other $(0.42)$ than to the mixed conifer site (both hydric pygmy sites, 0.13 ).

\section{Discussion}

\section{Mixed conifer versus hydric pygmy}

Mixed conifer and hydric pygmy have both similarities and differences based on the presence of ECM taxa. Both plant community types share $C$. geophilum and members of the 
Thelephoraceae. Of the six taxa in the mixed conifer community type, three are in the Thelephoraceae. Russuloid 1 and a Tuber sp. were only detected in the mixed conifer site. The ECM taxa observed in the mixed conifer community type bear a resemblance to other ECM communities in coniferous forests of California (all being rich in Thelephoraceae and Russulaceae spp.; Taylor and Bruns 1999; Stendell et al. 1999; Horton and Bruns 1998; Horton et al. 1999).

Members of the Cortinariaceae and Suillus tomentosus only appeared in hydric pygmy sites, and these types made up over half of the taxa in hydric pygmy. Cortinariaceae spp. and Suillus tomentosus have been observed in late-stage forests (Visser 1995), and Cortinariaceae spp. were also observed in undisturbed forests in Wyoming, U.S.A. (Byrd et al. 2000). Although abundance was not measured in this study, C. geophilum was clearly the most abundant ECM type in hydric pygmy sites. Cenococcum geophilum has a worldwide distribution (Smith and Read 1997) and has also been reported as the dominant taxon in clear-cut forests (Byrd et al. 2000), and old-growth and mature forests on Vancouver Island, Canada (Goodman and Trofymow 1998).

The hydric pygmy sites were more similar to each other than to the mixed conifer site. The distribution of ECM types across two plant community types may indicate that some ECM are more adapted to one plant community type over another. Adaptations could include biotic (host specificity; a different Pinus species characterized each plant community), or abiotic (soil fertility or hydrology). Several sitespecific ITS-RFLP types characterized all three sites. This observation could be a reflection of the spatial heterogeneity of ECM fungi (Stendell et al. 1999; Jonsson et al. 1999) and that ECM communities are characterized by several rare taxa that may be difficult to detect (Gehring et al. 1998; Stendell et al. 1999).

\section{ECM morphotyping versus ITS-RFLP}

ECM tips of the same morphotype collected from the same site all produced identical ITS-RFLP patterns. However, ECM morphotypes were not always discrete ITS types. Kårén and Nylund (1997) also observed inconsistencies between morphotypes and ITS-RFLP types. In our study, all ECM morphotypes and ITS-RFLP types were compared across different sites (Table 2), and there were two main discrepancies. First, an individual taxon produced different morphologies. Second, similar morphologies were produced by different taxa.

We observed different ECM morphologies within an ITSRFLP type. Morphotypes Pe and Yc (Thelephoroid 1) differed in mantle color, Oc and $\mathrm{O}$ (Russuloid 1) differed in the presence or absence of cystidia, Brr and $\mathrm{Ob}$ (Tomentella sublilacina) differed slightly in mantle patterns, and Wyr and $\mathrm{Yb}(2)$ (Dermocybe sp.1) differed in mantle and extramatrical hyphal color, as well as the presence of rhizomorphs. In three of these four cases, the ECM morphology of a particular ECM taxon varied to some degree on the same host within the same plant community.

We also observed that different taxa produced a common morphotype. Morphotypes $\mathrm{Yb}$ and $\mathrm{O}$ each represented two ITS-RFLP types. These findings reveal that morphological overlap exists across ECM fungal taxa, and that in systems with high ECM fungal diversity, a great number of morpho- logical characteristics will need to be evaluated to differentiate ECM taxa.

\section{Cenococcum geophilum}

The ITS region of $C$. geophilum sometimes contains an intron (Rogers et al. 1993). In our study, it is likely that the presence and absence of the intron produced two different RFLP patterns (ITS-RFLP types 1 and 2). ITS-RFLP type 1 matches the RFLP pattern of $C$. geophilum sclerotia, and type 2 is comparable with the reported RFLP patterns of C. geophilum (Horton and Bruns 1998).

In the hydric pygmy sites, morphotype Bh (C. geophilum) produced two ITS-RFLP types, and both types were evaluated from each individual root tip. Kårén and Nylund (1997) also observed that $C$. geophilum consisted of several ITS types. One explanation the researchers give is that C. geophilum has been found to concurrently colonize roots with other fungal taxa (Zak and Marx 1964, in Kårén and Nylund 1997). In our study, it also appears that C. geophilum co-colonizes roots with another ITS type. One RFLP pattern is similar to $C$. geophilum, while the other is similar to Phialophora-like (Baar et al. 1999). Phialophora species belong to the dark septate endophytes (DSE) group, which have been observed on many plant species, and found to colonize roots concurrently with ectomycorrhizas (Jumpponen and Trappe 1998). DSE were observed on roots of all plant species in hydric pygmy (Wurzburger and Bledsoe 2001).

ECM morphotyping and molecular analyses provided both contradictory and complementary results. The same taxon can produce different ECM morphologies, and different taxa can produce similar ECM morphologies. These results indicate that surveys of ECM fungi based on morphology alone are not sufficient. However, in this study, all ECM root tips of a distinct morphotype from the same site produced identical RFLP patterns. We believe that these results demonstrate the value in using ECM morphology to group types prior to molecular analysis. The mixed conifer and hydric pygmy plant communities contain different Pinus species and have marked differences in soils and hydrology. It is possible that these environmental factors are influential in the differences we observed in ECM taxa across these two plant communities.

\section{Acknowledgements}

This research was supported by a University of California, Davis, Jastro Shields research fellowship to N.W. and National Science Foundation grant No. DEB-95927722 to C.S.B. We thank J. Lansing, M. Allen (University of California, Riverside, Calif.), and T. Bruns and his research group (University of California, Berkeley, Calif.) for their guidance, tremendous generosity, and use of laboratory facilities. We thank T. Horton for helpful comments about the manuscript. We are grateful for permission to collect samples in the Jug Handle State Reserve and the Jackson State Forest.

\section{References}

Agerer, R. 1991. Characterization of ectomycorrhiza. In Methods in microbiology. Vol. 23. Edited by J.R. Norris, D.J. Read, and A.K. Varma. Academic Press, New York. pp. 25-73. 
Allen, E.B., Allen, M.F., Helm, D.J., Trappe, J.M., Molina, R.M., and Rincon, E. 1995. Patterns and regulation of mycorrhizal plant and fungal diversity. Plant Soil, 170: 47-62.

Baar, J., Horton, T.R., Kretzer, A.M., and Bruns, T.D. 1999. Mycorrhizal colonization of Pinus muricata from resistant propagules after a stand-replacing wildfire. New Phytol. 143: 409-418.

Byrd, K.B., Parker, V.T., Vogler, D.R., and Cullings, K.W. 2000. The influence of clear-cutting on ectomycorrhizal fungus diversity in a lodgepole pine (Pinus contorta) stand, Yellowstone National Park, Wyoming, and Gallatin National Forest, Montana. Can. J. Bot. 78: 149-156.

Cairney J.W.G. 1999. Intraspecific physiological variation: implications for understanding functional diversity in ectomycorrhizal fungi. Mycorrhiza, 9: 125-135.

Egger, K.N. 1995. Molecular analysis of ectomycorrhizal fungal communities. Can. J. Bot. 73(Suppl. 1): S1415-S1422.

Gardes, M., and Bruns, T.D. 1993. ITS primers with enhanced specificity for basidiomycetes-application to the identification of mycorrhizae and rusts. Mol. Ecol. 2: 113-118.

Gardes, M., and Bruns, T.D. 1996a. Community structure of ectomycorrhizal fungi in a Pinus muricata forest: above- and below-ground views. Can. J. Bot. 74: 1572-1583.

Gardes, M., and Bruns, T.D. 1996b. ITS-RFLP matching for identification of fungi. Methods Mol. Biol. 50: 177-186.

Gehring, C.A., Theimer, T.C., Whitham, T.G., and Keim P. 1998. Ectomycorrhizal fungal community structure of pinyon pines growing in two environmental extremes. Ecology, 79: 1562-1572.

Goodman, D.M., and Trofymow, J.A. 1998. Comparison of communities of ectomycorrhizal fungi in old-growth and mature stands of Douglas-fir at two sites on southern Vancouver Island. Can. J. For. Res. 28: 574-581.

Horton, T.R., and Bruns, T.D. 1998. Multiple-host fungi are the most frequent and abundant ectomycorrhizal types in a mixed stand of Douglas fir (Pseudotsuga menziesii) and bishop pine (Pinus muricata). New. Phytol. 139: 331-339.

Horton, T.R., Bruns, T.D., and Parker, V.T. 1999. Ectomycorrhizal fungi associated with Arctostaphylos contribute to Pseudotsuga menziesii establishment. Can. J. Bot. 77: 93-102.

Jonsson, L., Dahlberg, A., Nilsson, M.-C., Zackrisson, O., and Karen, O. 1999. Ectomycorrhizal fungal communities in latesuccessional Swedish boreal forests, and their composition following wildfire. Mol. Ecol. 8: 205-215.

Jumpponen, A., and Trappe, J.M. 1998. Dark septate endophytes: a review of facultative biotrophic root-colonizing fungi. New Phytol. 140: 295-310.

Kårén, O., and Nylund, J.-E. 1997. Effects of ammonium sulphate on the community structure and biomass of ectomycorrhizal fungi in a Norway spruce stand in southwestern Sweden. Can. J. Bot. 75: 1628-1642.

Kranabetter, J.M., Hayden, S., and Wright, E.F. 1999. A comparison of ectomycorrhiza communities from three conifer species planted on forest gap edges. Can. J. Bot. 77: 1193-1198.

Massicotte, H.B., Molina, R., Tackaberry, L.E., Smith, J.E., and Amaranthus, M.P. 1999. Diversity and host specificity of ectomycorrhizal fungi retrieved from three adjacent forest sites by five host species. Can. J. Bot. 77: 1053-1076.

Molina, R., Massicotte, H., and Trappe, J.M. 1992. Specificity phenomena in mycorrhizal symbioses: community-ecological consequences and practical implications. In Mycorrhizal functioning, an integrative plant fungal process. Edited by M.F. Allen. Chapman \& Hall, New York. pp. 357-423.

Rogers S.O., Yan, Z.H., Shinohara, M., LoBuglio, F., and Wang, C.J.K. 1993. Messenger RNA intron in the nuclear 18s ribosomal RNA gene of deuteromycetes. Curr. Genet. 23: 338-342.

Smith, S.E., and Read, D.J. 1997. Mycorrhizal symbioses. Academic Press, London.

Stendell, E.R., Horton, T.R., and Bruns, T.D. 1999. Early effects of prescribed fire on the structure of the ectomycorrhizal fungus community in a Sierra Nevada ponderosa pine forest. Mycol. Res. 103: 1353-1359.

Taylor, D.L., and Bruns T.D. 1999. Community structure of ectomycorrhizal fungi in a Pinus muricata forest: minimal overlap between the mature forest and resistant propagule communities. Mol. Ecol. 8 1837-1850.

Visser, S. 1995. Ectomycorrhizal fungal succession in jack pine stands following wildfire. New Phytol. 129: 389-401.

White, T.J., Bruns, T.D., Lee, S.B., Taylor, J.W. 1990. Amplification and direct sequencing of fungal ribosomal RNA genes for phylogenetics. In PCR protocols: a guide to methods and applications. Edited by M.A. Innis, D.H. Gelfand, J.J. Sninsky, and T.J. White. Academic Press, London. pp. 315-322.

Wurzburger, N., and Bledsoe, C.S. 2001. Comparison of ericoid and ectomycorrhizal colonization and ectomycorrhizal morphotypes in mixed conifer and pygmy forests on the northern California coast. Can. J. Bot. 79: 1202-1210.

Zak, B., and Marx, D.H. 1964. Isolation of mycorrhizal fungi from roots of individual slash pines. For. Sci. 10: 214-222. 